\title{
UNDERSTANDING AND MANAGING BIODIVERSITY IN RELATION TO NATIVE CRAYFISH POPULATIONS IN EUROPE
}

\author{
F. GHERARDI (1), C. SOUTY-GROSSET (2), J. REYNOLDS (3)
}

(1) Dipartimento di Biologia Animale e Genetica «Leo Pardi ", Università di Firenze, Via Romana 17, 50125 Firenze, Italy.

E-Mail : gherardi@dbag.unifi.it

(2) UMR CNRS 6556 "Génétique et Biologie des Populations de Crustacés ", Université de Poitiers, 40, avenue du Recteur Pineau, F-86022 Poitiers Cedex, France.

E-Mail : catherine.souty@univ-poitiers.fr

(3) Department of Zoology, University of Dublin, Trinity College, Dublin 2, Ireland.

E-Mail : irynolds@tcd.ie

\begin{abstract}
The loss or diminution of European crayfish populations because of both habitat deterioration and competition with alien crayfish - also responsible for the dissemination of the crayfish plague - would reduce the biodiversity at the species level. The topic "What is meant by biodiversity?" in the context of native freshwater crayfish in Europe was discussed during the Kilkenny CRAYNET meeting in order to make the point about the varied meanings of biodiversity from genes and individuals to population levels.
\end{abstract}

Key-words : biodiversity, native crayfish, conservation, management.

\section{COMPRÉHENSION ET GESTION DE LA BIODIVERSITÉ CONCERNANT LES POPULATIONS D'ÉCREVISSES NATIVES D'EUROPE}

\section{RÉSUMÉ}

La perte ou la diminution des populations d'écrevisses en Europe, à cause d'une part de la dégradation de l'habitat et d'autre part de la compétition avec les écrevisses exotiques introduites - et responsables de la dissémination de la peste de l'écrevisse - doit réduire la biodiversité au niveau de l'espèce. "Quelle est la signification de la biodiversité ? " dans le contexte des écrevisses natives d'Europe a été un sujet débattu au cours de la réunion CRAYNET de Kilkenny afin de faire le point sur la biodiversité au niveau du gène et de l'individu à celui de la population.

Mots-clés : biodiversité, écrevisses autochtones, conservation, gestion.

\section{INTRODUCTION}

Biodiversity is expressed as a core concern of a number of EC networks, united through the EC 5th Framework Programme under the structure "BIOTA Cluster", a European scientific response to the Convention on Biological Diversity and aiming to determine and promote strategic approaches to biodiversity conservation and management in Europe. CRAYNET is thus linked to BIOTA Cluster and among other linked projects, Bio Platform 
is a European platform for biodiversity aiming to improve the effectiveness and relevance of European diversity research, to contribute to European Research Area for Biodiversity and to promote the dissemination of current best practices and information regarding the scientific understanding of biodiversity conservation.

At the round table during the CRAYNET meeting in Kilkenny four general questions - based on a Bio platform e-conference entitled "Biotic resources in a changing world: science for a better governance" - have been addressed:

1. What do we mean by biodiversity?

2. How dependent are we on biodiversity?

3. What are the associated risks of such dependence?

4. How can we apply our knowledge to address this and to ameliorate the situation?

The present article is an attempt to integrate a number of points that have emerged from the E-conference discussions about flora and fauna but specifically discussed here in terms of crayfish situation in Europe.

\section{BIODIVERSITY AS A CONCEPT AND A MEASURABLE ENTITY}

Several authors (e.g. GASTON, 1998) have emphasised the multiplicity and range of meanings that have been associated with the term "biological diversity" and its 1986 contraction "biodiversity". This confused semantics is an obvious consequence of the increasing use - and sometimes abuse - of the word within the scientific literature, but it is also the inevitable effect of its adoption by a growing number of spheres besides academia, such as conservation, law, media, politics, science administration. Although the word "biodiversity" has already gained wide currency in the absence of a clear and unique meaning, greater precision will be required of its users in order that policy and programs could be more efficiently defined in the future. Our belief is that a demolition of the Tower of Babel in conservation biology would provide benefits to all concerned with this endeavour and obviously to its beneficiaries.

Biodiversity as a concept refers to the variety of life forms (plants, animals and microorganisms), the genes they contain, and the communities they form within ecosystems (see, e.g., The Convention on Biological Diversity, United Nations Environment Programme 1992). In terms of crayfish, this may relate to population genetic variability, to sympatric crayfish species, and to the macroinvertebrate community containing these species. However, given that the concept of biodiversity must reflect the goals of conservation, more useful than a definition would be "a characterisation of biodiversity that identifies the major components at several levels of organisation", by analysing in the area under concern the "composition" of biodiversity (i.e. species lists and measures of species diversity and genetic diversity), its "structure" (i.e. the physical organisation or pattern of a system, from habitat to landscape complexities), and its "function" (evaluated through ecological and evolutionary processes) (NOSS, 1990). Obviously, the pool of living diversity is dynamic. It increases when new genetic variation is produced through the process of evolution and a new species is created or a novel ecosystem is formed, while it decreases when the genetic variation within a species decreases, a species becomes extinct or an ecosystem complex is degraded or lost.

Biodiversity must be viewed also as a measurable entity. Management requires measurements, and measures of biodiversity only become possible when some quantitative value can be ascribed to them and when these values can be compared (GROOMBRIDGE, 1992). In the context of European crayfish, biodiversity under this connotation may be measured at three levels: (1) genetic diversity, occurring within and 
between populations of crayfish species as well as between species; (2) species diversity, quantified as the variety of living species in an ecological unit, such as crayfish in stream banks; and (3) ecosystem diversity, relating to the variety of habitats, biotic communities and ecological processes, as well as the tremendous diversity present within ecosystems in terms of habitat differences and of the variety of ecological processes.

From this perspective, species can be weighed on the basis of their ecological role and grouped into functional categories, provided that the ecological role of a species can have a direct effect on the community structure and therefore on overall biological diversity. The ecological role of freshwater crayfish as keystone species in the community appears fundamental.

The quantitative assessment of diversity at the ecosystem, habitat, or community level remains more problematic than that at organismal level. A number of factors may make such measurement and assessment of diversity at this level poorly defined. Many different "units" of diversity are involved at the supra-species level that include patterns of habitats in the community, relative abundance of species, age structure of populations, patterns of communities in the landscape, trophic structure, and patch dynamics. Predator-prey relationships (including the impact of man) are important in the case of crayfish. Further confounding influences are the impact of historical or recent translocations of species, restocking of depleted areas, etc. The management of freshwater crayfish has been going on for a long time, while their community dynamics have only recently been studied.

However, by conserving biodiversity at the ecosystem level, not only are the constituent species preserved, but also the ecosystem functions and services protected. These include nutrient and pollutant cycling, climate control, as well as non-consumptive recreation, scientific and aesthetic values (see, e.g., NORTON and ULANOWICZ, 1992).

Given the complexities of defining biodiversity at community or ecosystem level, a range of different approaches to measuring ecosystem diversity exist. Any number of community attributes is components of biodiversity and may deserve monitoring for specific objectives. There are several generic measures of community level diversity, including biogeographically realms or provinces, based on the distribution of species, and eco-regions or eco-zones, based on physical attributes such as soils and climate. All these apply to freshwater crayfish in Europe.

\section{WE DEPEND ON BIODIVERSITY}

In Europe, it seems impossible to find a habitat, landscape, eco-region, or any other large-scale biological system in pristine condition. In practice all "natural systems" on this continent have been altered to various degrees by direct or indirect human influence. In many cases human-related transformations have contributed to a higher biodiversity, although this cannot be equated to higher conservation value. Thus, small scale patchwork agriculture will have higher diversity than a steppe, and an exploited forest will be more diversified than a closed canopy climax stand. This situation is particularly relevant to crayfish in Europe. Therefore, the human component must always be taken into account when evaluating biodiversity.

In high numbers, however, humans also trigger biodiversity losses and affect the quantity and quality of services provided by the environment, adapting themselves to changes in environmental services by modifying their behaviour. This is well exemplified by human pressures on crayfish, including poaching, over-fishing, and degrading of water quality.

Today humans are dependent on fundamental biological systems and processes for their sustenance, health, well-being, and enjoyment of life. Humanity derives all of 
its food and many medicines and industrial products from the wild and domesticated components of biological diversity. Biotic resources also serve recreation and tourism, and underpin the ecosystems, which provide us with many services. Thus, biodiversity is vital for humans, including the variety of game species, timber and medicinal plants, and functional elements of biodiversity such as regulation of climate, carbon sequestration, decomposition, maintenance of hydrological cycles, pollination etc. But to look at the economic argument another way, can we say that the only species worth saving are those of economic importance?

In pragmatic terms, a species may be a source of products useful to people - thus, conservation has an economic basis (COSTANZA et al., 1997). Total economic value is the sum of "use values" (consumption, amenities, options, exploration) and "non-use values" - either existence (e.g. fees paid to see heritage items) or bequest (donations, conservation for future generations). Thus, benefits arising from the conservation of components of biological diversity can be (1) ecosystem services (e.g. water resources), (2) biological resources (e.g. crayfish as food), and (3) social benefits (in research; education and monitoring; recreation and cultural value).

From a biological perspective, diversity is vital, because it allows the human population and other species to adapt to environmental changes. Generally, the conservation of components of biological diversity, such as freshwater crayfish, produces benefits arising from the protection of the aquatic environment and water resources, as well as from the maintenance of either food sources or cultural heritage. Concerning Astacus astacus, T. Taugbøl (Norway) highlighted in Kilkenny and at the Halden CRAYNET meeting that the species is highly valued both from a recreational and economic point of view and pointed out that exploitation is a prerequisite for its conservation. As the greatest threat is the spread of crayfish plague following the introduction of alien crayfish, if local people are allowed to catch and benefit from this noble crayfish, this is the best protection against illegal stocking of aliens. (Concrete examples from Norway will be provided in the next BFPP volume devoted to European native crayfish with a special focus on Astacus astacus: linking socioeconomics and conservation.). Social benefits also follow, in terms of research, education, and recreation.

\section{THERE ARE RISKS ASSOCIATED TO OUR DEPENDENCY ON BIODIVERSITY}

Biodiversity thus provides a huge variety of goods and services, from food and water to chemicals and tourist attractions. Human society depends on these biological resources that are threatened by anthropogenic pressures. Freshwater crayfish have both a defined monetary and cultural value in Europe, particularly in the native genus Astacus, but also in the case of the established aliens Pacifastacus leniusculus and Procambarus clarkii. The interrelationship between biodiversity and natural resources, in the broad sense, acquires a broader interest under the perspective of global change dynamics, both at physical and biosphere levels and at the socio-economic domain. For example, climate change is expected to cause negative impacts upon fisheries, a major biotic resource, and the use and trade of species or genes in a global economy may generate conflicts over Intellectual Property Rights, a major issue of international politics.

In terms of European crayfish, the clearest case may be made for use values of Astacus species, whose commercial harvest and associated value-added tourism and heritage features may be important supports to the local economy in northern Europe. However, Austropotamobius species may be increasingly considered as having non-use values. In fact, socio-economic and traditional cultural values cannot be clearly separated in terms of freshwater crayfish. For example, the traditional Scandinavian festivals in August provide considerable tourist revenue to crayfish regions, which in its turn emphasises the 
importance of management of these valuable stocks (see the Norwegian case, above). In contrast, no such value is added in relation to maritime lobster fisheries.

Less tangible resources are the sights, sounds and smells of plants, animals and landscapes. Catching sight of a crayfish in a brook is such an element. Thus, while the economic benefits of such resources may be considerable, the value of biological diversity is not restricted to these. The enormous diversity of life in itself is of crucial value, demonstrably in some cases giving greater resilience to ecosystems and organisms.

Biodiversity has important social and cultural values. To argue that biodiversity should be conserved for its cultural value has a good deal of merit, if you can persuade people that each species has the equivalent complexity of a great city, and that in itself this complexity forms part of our cultural heritage. For crayfish this is still possible because our grandfathers fished the native species, although Austropotamobius species are now protected from exploitation. But we suspect that this is an argument that has limited appeal for many people on the planet, for whom a bug in a tree has nothing in common with their view of cultural heritage.

While this will not be further developed here, biodiversity has a social value. The crux of the argument is that humans are today the main agent of change, and our views of what we should do about that change depends entirely on our social perspectives. Human exploitation, or indifference, has led to countless extinctions of species and alteration to ecosystems, and native crayfish are among those species most threatened. The problem comes when society must decide to invest energy into conservation and that energy does not come free of cost. This cost implies trade-offs and compromises - what are the political realities of sacrificing something?

\section{HOW CAN WE APPLY OUR KNOWLEDGE TO CONSERVE BIODIVERSITY?}

A better formulation might be: how best to synthesise our knowledge to understand the benefits associated with our dependency on biodiversity?

There is considerable knowledge about the structural and compositional aspects of biological diversity, but there is less information about its functional elements and especially about the relationship between structure/composition and function. This holds true for many aspects of crayfish biology. Ongoing research will increase our knowledge, through synthesis of scientific information, and understanding of its social applications, thus including both scientists and other stakeholders.

The notion of ecosystems services represents a key way to synthesise our knowledge to assess biodiversity. Determining how ecosystem services relate to change in species composition and ecosystem processes requires integrating population and community ecology, ecosystems dynamics, and economics.

In relation to biodiversity in general, scientific research is needed to identify and delineate the network of eco-regions in the scale of the planet and to determine what is indispensable for securing their further existence, as well as to understand:

- How biodiversity supplies the resources on which we depend.

- The feedbacks between biodiversity simplification and climate change.

- The ecology of extinction.

- How European societies manage the conflicts that arise when efforts to conserve biodiversity restrict economic and other human activities. 
- In relation to further ecological studies on crayfish, we need to consider the following and through CRAYNET to develop appropriate protocols for management actions, which can be tested and further refined:

- What is an appropriate time span and season for the studies?

- Can we compile a series of indicators for scooping a study?

- How do we deal with obscure or taxonomically difficult groups that are nonetheless part of biodiversity?

- What do we do with all the historical records that do not conform to the new data?

- How are we to decide on standardised protocols for making numerical biodiversity assessments?

- Can we agree on the relative importance of the biodiversity indicated for the groups studied?

- Can we link this sort of approach to the politico-socio-economic background of the decision makers?

A first step in management is to provide an inventory and description of local knowledge of biodiversity and sustainable use of its components. We then need to understand the status and trends of local knowledge in Europe (are local crayfish threatened?) and to understand the extent to which European indigenous people or local communities restrict access to local knowledge or treat it as a common good. We need to understand the local arguments (which combine both knowledge and values) and to enrich the debate with our scientific knowledge (biological as well as economic, social or cultural). We should then propose structures that help in finding a decision (these can be participatory approaches, decision support with an open value basis, such as nonutilitarian multi-criteria decision aid) and, finally, help in implementing these decisions.

\section{CONCLUSIONS}

There is a need for a standardised approach in biodiversity assessments. The Natura 2000 Network, as a universal system to maintain biodiversity in biogeographically regions, may serve as a basis for comparison of actual biodiversity levels throughout Europe. As white-clawed crayfish are listed for protection under European Legislation such as the Fauna and Habitats directive (93/43/EEC), a number of Special Areas of Conservation (SACs) have been proposed for freshwater crayfish in every European country. For example the Irish government has selected 14 sites as SACs for Austropotamobius pallipes on the basis of the best available published and unpublished information (REYNOLDS et al, 2002). In the U.K., the Joint Nature Conservation Committee (JNCC:http://www.jncc.gov.uk/ ProtectedSites/SACselection/species.asp?FeaturelntCodeS 1092) notes that there is a relatively low proportion of the total UK $A$. pallipes population contained within the SAC due to the fact that many recorded populations are in areas vulnerable to crayfish plague. In the UK and some other European regions, national legislation or local by-laws allow more stringent or flexible management and control. Thus, although alien crayfish species are widely established, the UK has designated "No-Go" areas. MAFF (1994) has circulated a consultation letter regarding a change in the use of the Import of Live Fish Act 1980: paragraph 13 of this document proposes that "the keeping and release of non-native crayfish will be forbidden in certain specified areas (no-go areas) except under licence" (in ROGERS and HOLDICH, 1995). This is a good example of how to make the best of a bad situation. 
For every habitat type recognised under Natura 2000, it would be necessary to make an assessment of potential biodiversity level (under hypothetical natural conditions) in an agreed standard way. Such a standard should be universal enough to be applied to the whole range of European habitats and not too complicated in order to be used for further routine monitoring.

In agreement with ideas from the E-conference, we conclude that biodiversity should not be conceptually fragmented into "bits to conserve" and "bits to abandon". Since the maintenance of biodiversity through protection of selected components of the biosphere is limited in its effectiveness, the introduction of a new concept, the eco-region as the basic unit for biodiversity conservation is suggested as a suitable way to conserve biodiversity within functional units that encompass all levels of biological organisation from genes to the landscape, and include all biological resources at the regional level. The ecoregion unit is seen as functionally homogenous in the ecological sense, and one where many or all levels of biological organisation are presented. European legislation is starting to recognise such units, e.g. of relevance to crayfish is the catchment as a basic water quality management unit under the Water framework Directive. However, management still needs to understand the benefits and impacts of restocking and translocation of aquatic organisms, including the addition of parasites, pathogens and commensal species, e.g. the spread of crayfish plague across Europe (see the hazard analysis of pathogens of freshwater crayfish exotic to Europe, which is the first step of import risk analysis in EDGERTON, 2002a and 2002b), e.g. the spread of crayfish plague across Europe.

The debate on potential and risks of biotic resources may be based around attempts to compare the various values and benefits of preserving biodiversity on a moral ground, and rejection of the idea of conserving only those elements of biodiversity that humans identify as procuring tangible biological resources.

\section{REFERENCES}

COSTANZA R., D'ARGE R., DE GROOT R., FARBER S., GRASSO M., HANNON B., LIMBURG K., NAEEM S., O'NEILL R.V., PARUELO J., RASKIN R.G., SUTTON P., VAN DEN BELT M., 1997. The value of the world's ecosystem services and natural capital. Nature, 387, 253-260.

EDGERTON B.F., 2002a. A review of international biosecurity policy development in relation to movements of freshwater crayfish. In: SOUTY-GROSSET C., GRANDJEAN F., Eds. 2002. Knowledge-based management of European native crayfish, Crayfish special volume 4, Bull. Fr. Pêche Piscic., 367, 805-812.

EDGERTON B.F., 2002b. Hazard analysis of exotic pathogens of potential threat to European freshwater crayfish. In: SOUTY-GROSSET C., GRANDJEAN F., Eds. 2002. Knowledge-based management of European native crayfish, Crayfish special volume 4, Bull. Fr. Pêche Piscic., 367, 813-820.

GASTON K.J., 1998. Biodiversity. Pp. 1-19. In: SUTHERLAND W.J. (ed.) Conservation science and action. Blackwell Science Ltd, Oxford.

GROOMBRIDGE B., 1992. Global biodiversity. Chapman and Hall, London.

MAFF, 1994. Conservation of native crayfish (Austropotamobius pallipes). Consultation letter. Ministry of Agriculture, Fisheries and Food, London, $13 \mathrm{p}$.

NORTON B.G., ULANOWICZ R.E., 1992. Scale and Biodiversity Policy: A Hierarchical Approach. Ambio, 21, 244-249. 
NOSS R., 1990 Indicators for Monitoring Biodiversity: A Hierarchical Approach. Conservation Biology, 4, 355-364.

REYNOLDS J.D., DEMERS A., MARNELL F., 2002. Managing an abundant crayfish resource for conservation. In: SOUTY-GROSSET C., GRANDJEAN F., Eds. 2002. Knowledge-based management of European native crayfish, Crayfish special volume 4, Bull. Fr. Pêche Piscic., 367, 823-832.

ROGERS W.D., HOLDICH D.M., 1995. Conservation and management of crayfish in Britain. Freshwater Crayfish, 10, 92-97.

UNITED NATIONS ENVIRONMENT PROGRAMME, 1992. Convention on Biological Diversity. Nairobi, Kenya. http://www.biodiv.org/. 